\title{
Determinants of the Use of Fintech Finance among Chinese Small and Medium-Sized Enterprises
}

\author{
Xiang, Dong \\ Zhang, Yuming \\ Worthington, Andrew C
}

\begin{abstract}
FinTech, the merging of finance and modern Internet-based technology, has rapidly presented itself as a disruptor to traditional business financing, notably in the form of crowdfunding and Peer-to-Peer (P2P) lending. In this paper, we examine the determinants of the use of FinTech finance by businesses, with a particular focus on the ownership, governance, and business practices that may modify the relationships with conventional motivations for external finance. Using a comprehensive sample of Chinese hi-tech small and medium-sized enterprises (SMEs), we find that state-owned enterprises (SOEs) and family firms and financially constrained firms are respectively much less and much more likely to seek FinTech finance. In the Chinese context, we argue that part of this may be because of the relative ease with which SOE SMEs can access cheaper conventional finance through SOE banks. The quality of traditional relationship banking also affects the relative desirability of FinTech financing. As for family firms, we find that innovation, as exemplified by R\&D activity, effectively overrides any conventional reluctance to access external finance, suggesting the relative benefits of FinTech finance for innovative high-growth firms.
\end{abstract}

Managerial relevance statement - Based on a comprehensive sample of Chinese hi-tech small and medium-sized enterprises (SMEs), our paper is the first empirical analysis on the effects of China's FinTech on business finance, and the first empirical analysis on the relationship between SMEs' (R\&D) financial constraint and FinTech., we find that state-owned enterprises (SOEs) and family firms and financially constrained firms are respectively much less and much more likely to seek FinTech finance. Our central argument is that the unique characteristics of SMEs such as state and family ownership can lead to outcomes very different from those for other firms when applying for finance, especially the forms of finance exemplified by FinTech. 


\section{Introduction}

In just a few years, FinTech, a neologism describing the fusion of finance and technology, has become the business catchword of the day. While technology and finance have long coexisted, it is only recently that this joint promise has been fully realized, describing the connection of modern, mainly internet-related, technologies (such as big data, cloud computing, and mobile Internet) with long-established business activities in the financial services industry (including loans, financial advice, budgeting, payments, and data analysis). Currently, FinTech operate in four major finance segments, being financing, asset management, and payments, along with insurance, information communication technology (ICT) and infrastructure, etc. [1]. In what follows, we focus on FinTech financing, which includes crowdfunding and Peer-to-Peer (P2P) lending, and which has shown promise to transform business practice of all types.

Against this background of rapid and extensive financial innovation and disruption often lies a business environment seemingly as old as time. Especially in the developing world, and particularly among small and medium-sized enterprises (SMEs), the hand of history lays heavy. In little more than half a century, China has transformed itself from a centrally planned closed economy to a global manufacturing and exporting hub, achieved economic growth averaging 10\% annually, and become the world's second-largest economy. Yet a huge number of state-owned enterprises (SOEs) in China, including SMEs, remain under the control of the Chinese central or local governments. Even after decades of reform, the socialist legacy is still apparent in these SOEs through higher levels of capital accumulation, preferential access to financial resources, profits from monopoly rights in a number of industries, and protection from foreign competition [2].

This is important because of the proven link between state ownership and inefficiency and underperformance [3], [4]. A major cause of this inefficiency is that state ownership is more likely than 
private ownership to suffer from the soft-budget constraints formulated by Kornai [5], [6]. From the other side of the FinTech equation, state-owned banks dominate China's financial system [7]. Combined together, the better access of SOEs to state-owned banks and the willingness of these banks to provide loans in line with broader policy concerns, such as improving the employment rate and enhancing social stability, suggests that complications in ownership may act against the realization of the promise of FinTech in providing efficient and effective financing.

At the same time, many Chinese non-SOE SMEs are family firms and this likewise is argued to influence firm financing behaviors in areas where FinTech potentially offers most advantage. While family firms have some advantages in that as owner-managers that they can mitigate agency conflicts between owners (principals) and managers (agents) [8], there is also the argument that family firms remain mired in tradition and are reluctant to seek external financing for fear of losing control.

Accordingly, our central argument is that the unique characteristics of SMEs such as state and family ownership can lead to outcomes very different from those for other firms when applying for finance, especially the forms of finance exemplified by FinTech. This is seemingly despite the pace of innovation in these same firms, especially in developing economies like China where state-owned and family firms dominate the SME sector. Using a sample of Chinese hi-tech SMEs, we find that firm ownership has a significant influence on FinTech finance in that both state-owned and family firms are less likely to seek FinTech finance with odds ratios of $38.7 \%$ and $78.7 \%$ respectively. We also find that firms with financial constraints are much more likely to seek FinTech finance with an odds ratio of 1.714 . On this basis, we argue that state-owned firms may have better access to credit from state-owned banks. Another reason for lower FinTech-financing is that firms with a high level of state ownership may not need to hold high levels of cash 
as credit is readily available from state-owned banks, even if the firm becomes financially distressed and loses access to external private funding [9].

As for family firms also not seeking FinTech finance, we argue that family firms continue to strongly prefer internal financing (either from equity contributions by family shareholders or retained earnings) to external financing regardless of form. We also find that while increased R\&D for state-owned firms does not lead to higher levels of FinTech finance seeking, family ownership has a significant and positive effect on the relation between $R \& D$ intensity and FinTech finance with an odds ratio of 4.913. This says that innovative family firms are much more likely particularly to seek FinTech to finance their higher levels of R\&D.

Regarding the several other factors thought to affect the accessing of FinTech finance, we find that firms whose relationship banks are non-bank financial institutions are less active in using FinTech finance with odds ratios of $30.2-49.2 \%$. At the same time, firms that have shorter tenures of relationship banking are more likely to use FinTech finance with an odds ratio of $149.3-186.0 \%$. This may proves suggest that, for SMEs, FinTech finance, at this stage, are rather acting as a complementary financing source than an "attractive" and a MUST financing source.

The remainder of the paper is structured as follows. Section 2 provides a review of literature and develops the hypotheses used in the paper. Section 3 discusses the data, variables, and estimation models, including how we account for sample selection and endogeneity. Section 4 presents the results and Section 5 concludes.

\section{II.Literature review and hypotheses}

\section{A. Fin Tech and SME financing}


FinTech financing for businesses consists of two main components: crowdfunding and P2P lending. Crowdfunding is the funding of a project or venture by monetary contributions from a large number of persons. There are usually three parties in a crowdfunding arrangement: the initiator of the project or venture or the creator and known as the promoter; the organization providing the crowdfunding website or platform, known as the intermediary; and the individuals or entities that contribute or pledge money, known as contributors. Of the four known crowdfunding types, donation-, reward-, equity- and debt-based crowdfunding, it is the latter two that are the most relevant to commercial enterprises, whereby contributors make a payment in return for an equity interest or lend money to the promoter who in return agrees to pay interest and repay principal on the loan. Examples include Kickstarter, GoFundMe, EquityNet, Indiegogo, RocketHub, and Crowdfunder.

Second, peer-to-peer (P2P) lending is the lending of money to businesses through online services that directly match lenders with borrowers. The business loans made can be secured or unsecured and are available for a wide range of purposes. In the case of both crowdfunding and P2P lending, the argument is that because the intermediaries offering these services generally operate online, they have lower overheads and provide lending services more cheaply than traditional financial institutions, resulting in lower borrower costs. Examples of P2P lending platforms include Lending Club, Prosper, Upstart, and Funding Circle.

Because of their inherent informational opaqueness and the limited finance sources available SMEs generally require special attention [10]. SMEs are expected to suffer more from market failures such as a relative inability to capture the profits from investment [11], [12] and uncertainty [13], leading to information asymmetries between firms and external suppliers of finance, resulting in financial constraints and underinvestment in R\&D [12], [14]. Himmelberg \& Petersen [15] and Carpenter \& Petersen [16], focusing on independent high-tech, small and young firms conclude that these firms are most financially constrained. 
Both crowdfunding and $\mathrm{P} 2 \mathrm{P}$ lending are potentially able to mitigate the financial constraints and underinvestment for SMEs by alleviating information asymmetry and providing alternative financing sources with relatively lower levels of transaction costs for SMEs for the following five reasons.

First, online platforms, which differ from traditional funding channels, allow financial service providers to offer a wide range of new services that remove intermediaries and administrative layers to make transactions more effective and less prone to error. In this way, financial services are decentralized and made flatter. Second, networked access to financial services facilitates quicker access to all manner of transactions from checking financial status, making payments, and withdrawing and transferring funds. Third, they facilitate the activities of existing financial institutions. This involves the use of big data to deliver a more efficient service, but it also allows firms to use technology to manage legal risk more effectively. Fourth, in the absence of industry-wide standardization (i.e. no capital requirements as for banks) it is clear that crowdfunding and P2P platforms enjoy lower operating and capital expenses compared to traditional banks. Finally, FinTech creates efficiencies and competition that reduces online risk, but also making SMEs more profitable (WEF 2015) [17]. In particular, app-based companies are emerging everywhere.

Schwienbacher and Larralde [18] provide an overview of nascent equity crowdfunding literature in relation to entrepreneurial finance, in which they discuss why founders choose this source of funding. Hornuf and Schwienbacher [19] and Mollick [20] compare crowdfunding to different entrepreneurial financing options. Hemer [21] emphasizes that the funding process itself is the decisive difference, because investors make their decisions based on the information provided therein. Schwienbacher [22] suggests that one benefit of crowdfunding is reduced operating risks in that borrowers can reduce their operating risks by setting a pre-specified minimum in an all-or-nothing funding model at what they would need to cover their fixed costs. In addition, the relatively lower levels of risk for crowdfunding may derive from the proposition 
that the crowd may be wiser than experts, at least sometimes because crowdfunding involves the aggregation of information or preferences held by a large number of individuals.

Elsewhere, Hakenes and Schlegel [23] show that under certain conditions, an unsophisticated lending crowd may do better than a lending expert because the commitment of each individual may result in better information. Similarly, Larrick et al. [24] note that combining judgements of many helps cancel out outliers or errors or, as they write, smooths “...the rough edges to isolate the collective's view of the truth”. Balyuk [25] suggest that FinTech appear not to generate any new soft information not available to existing lenders. Instead, if they do improve information, it is likely to come through leveraging information from institutional lenders well positioned to obtain insights into credit market conditions and are active in deciding on whether or not to fund loans. Allen and Gale [26] argue that public markets can be superior to financial intermediaries in providing funding because diversity of opinion is valuable when information is inexpensive.

Drawing on the above perspectives, we state the following hypothesis:

Hypothesis 1. SMEs with severer financial constraints are more likely to seek FinTech finance.

\section{B. SME ownership and FinTech finance}

One unique feature of China's economy is that there are a large number of state-owned enterprises (SOEs) under the control of central or local governments. Even after 40 years of reform, the socialist legacy is still apparent in state-owned firms, for example through higher levels of capital accumulation, preferential access to financial resources, profits from monopoly rights in a number of industries, and protection from foreign competition [2]. There is also a long established link between state ownership and inefficiency and underperformance [3], [4]. A major cause of this inefficiency is that state ownership is more likely than private ownership to suffer from the soft-budget constraint effect first formulated by Kornai [5], [6]. In 
particular, state-owned banks dominate China's financial system [7]. Lin and Tan [27] and Cull and Xu [28], [29] document that SOEs in China have better access to credit in state-owned banks and can expect to receive financial help in times of distress. Megginson et al [9] argue that a firm with a high state ownership does not need to hold high level of cash since credit will be readily available from state-owned banks, even if the company becomes financially distressed and loses access to external private funding. Brandt and Li [30] and Ge and Qiu [31] find that Chinese state-owned banks are more likely to provide loans to SOEs due to political concerns, such as improving the employment rate and enhancing social stability. State-owned banks only seek to maximize their risk-adjusted returns when they offer loans to non-SOEs. Since state-owned banks have different incentives when they lend to SOEs and non-SOEs, the homogeneity of bank ownership and the heterogeneity of SMEs in China provide us with a great opportunity to investigate the relationship between ownership and financing. Thus, we hypothesis that,

\section{Hypothesis 2. State-owned SMEs are less likely to seek FinTech finance.}

Due to unique ownership structure, family ownership also may have an influence on firms' financing behaviors. The owner-manager structure of family firms has some advantages in terms of financing. First, as owner-managers, family firms can mitigate the conflicts arising from the misalignment of interests between owners (principals) and managers (agents) to prevent opportunistic management behavior, which in turn could result in Type 1 agency costs [8], [32]. Second, stewardship theory posits that stewards (managers) are intrinsically motivated and act altruistically for the benefit of the business and its principals (owners) [33]. Therefore, the goals of principals and stewards align and both parties pursue the same vision for the firm [34]. Third, the high level of personal involvement involved in day-to-day business engenders a strong sense of collective ownership and commitment to the firm [35], thus leading to few or no agency problems [36]. Lastly, family firms arguably have a longer-term orientation than do other firms [34], [37]. 
By planning to pass on the firm to their heirs [34], family firm owners work to create a successful firm in the long run, so they focus on things like customer loyalty and long-term relationships with stakeholders [37]. Thus, we construct the following hypotheses:

Hypothesis 3. Family SMEs are less likely to seek FinTech finance.

\section{SME innovation and Fin Tech finance}

Furthermore, we generally expect that innovative SMEs suffer more from market failures [11], [12]. Himmelberg and Petersen [15] and Carpenter and Petersen [16], focusing on independent high-tech, small and young firms conclude that these firms are most financially constrained. Westhead and Storey [38] explicitly compare the extent to which most technologically sophisticated small firms are more financially constrained than less technologically sophisticated ones and find that the former impede growth due to financial constraints. Goodacre and Tonks [39] state that innovation in high-tech industries is more likely to be of a new sort because it is more difficult for financiers to evaluate the investment. Storey and Tether [40] focus specifically on so-called New Technology-Based Firms (NTBFs) and emphasize their higher need of external financing, and others discuss their high innovative performance and growth [40], [41]. Based on the above literature, we have the following hypotheses,

Hypothesis 4a. Innovative SMEs are more likely to seek FinTech finance.

For SMEs, financing constraints can restrict R\&D much more than other forms of investment. Reasons include the lack of collateral value for R\&D “capital" and firms' need to protect proprietary information, even from potential investors [42]. Several studies (e.g. [43], [44]) find evidence suggesting that firms in the United States and other countries face financing constraints for R\&D. For the two sources for financing innovation projects i.e. external sources including bank loans or other debt contracts, and internal sources 
including retained profits or (new) equity, Brown et al [42] suggest that equity finance has several advantages over debt finance for hi-tech small firms. The main ones are: 1) there are no collateral requirements; 2) additional equity does not magnify problems associated with financial distress; and 3) internal equity finance does not create adverse selection problems. However, given that most SMEs have very limited capacity to get access to equity markets, especially the case in less developed financial markets such as in China, debt finance is still the major financing source for SMEs.

Again, the unique characteristics of SMEs such as ownership structure can lead to outcomes very different from those for other firms when financing innovative activities [45]. For example, conventional peckingorder theory would suggest that family firms prefer internal financing (either from equity contributions by family shareholders or retained earnings) to external financing [46], comprising equity and debt in order [47], [48]. Moreover, because family firms are more reluctant to dilute the family's control [49], they are usually less willing to raise capital through external equity offerings [47]. Drawing on these perspectives, we have the following hypothesis:

\section{Hypothesis 4b. Family-owned innovative SMEs are less likely to seek FinTech finance.}

In a similar vein, state ownership can be also an important determinant of the cross-sectional variance in firm R\&D. Zhang et al [50] find that the state sector has significantly lower efficiencies in both R\&D and productive activities than does the private sector. They also suggest that the reason why R\&D inefficiency of SOEs derive from R\&D intensity. In particular, a profit-maximizing firm such as private firms with a higher R\&D efficiency tends to spend more on R\&D. Boeing et al [51] also find that, in China, non-stateowned firms not only produce $R \& D$ of the highest quality but also are the only ownership type profiting from higher quality. In addition to the finance preferences for SOEs discussed above, we hypothesize that, 
Hypothesis 4c. State-owned innovative SMEs are less likely to seek FinTech finance.

\section{Data and method}

\section{A. Data}

For our analysis, we use data from the "China hi-Tech Small and Medium-sized Enterprises Dynamic Growth Survey" (CTSMEDGS). The CTSMEDGS is a major project of the National Social Science Fund of China (NSSFC), which began in 2015 with the objective of building a credit system and database for the purpose of financial evaluation, credit rating, and policy-related research for hi-tech SMEs. Our interest in this sector is not without reason, as Chinese hi-tech firms, both large and small, are growing rapidly and increasing their global reach.

The CTSMEDGS survey comprises basic firm information, firm external growth environments, and firm internal growth factors. The first wave of the CTSMEDGS is over the five-year period from 2015 to 2019. To ensure the effectiveness and reliability of the survey, four Chinese universities administered 10,000 questionnaires for the starting survey in 2015 through onsite distribution and collection. The firms sampled by the China Statistics Bureau and the State Administration for Industry and Commerce were from the literally millions of registered nonfinancial hi-tech firms in China employing fewer than 1,000 employees.

We start with the financial data in the 2015 CTSMEDGS for 2,683 hi-tech firms. We then exclude 106 firms with negative or zero net assets. For a similar reason, we exclude 352 firms with zero cash flow over the year, 209 financial firms because of their unique financing, and 831 firms with many missing observations. Our final sample comprises 1,185 hi-tech nonfinancial SMEs. Table 1 summarizes the data. 


\section{B. Variables}

1) Dependent Variable: The dependent variable derives from the survey question, "To what extent the firm makes use of on-line finance including crowdfunding and P2P lending”, a seven-point Likert scale from the extremely least use to extremely most use of FinTech finance. Though there are arguments regarding whether ordinal data of Likert-scale, converted to numbers, can be treated as interval data, we employ the ordinal data as dependent variable for ordered logit models [52], [53].

2) Variables of Interest: State Ownership: As a vital part of the "Reform and Opening" policy, SOEs in China have experienced ownership reforms since the 1980s in order to become more efficient and competitive. In 1995, the Chinese government adopted a policy epitomized by the slogan, "Keep only large firms and let small ones go." "Keep only large firms" meant the government would continue owning and controlling strategically important firms like those in resources, utilities, and energy. These surviving SOEs grew larger and more profitable, fulfilling the aims of policy reform. On the other side, "let small ones go," meant that smaller SOEs faced closure or immediate sale. Because most were unprofitable, local governments, the owners of the smaller SOEs, had strong incentive to restructure them [54]. The restructuring took such forms as debt equity swaps, ownership diversification, and employee shareholding, including management buyout. After a series of reforms, the Chinese government restructured most SOEs into joint stock companies with the government retaining a large share of ownership and even more of control. Initially, different government departments managed and supervised these state assets. Thus, despite the modern ownership structure, these incorporated firms are de facto SOEs. Chang and Jin [55] suggest that there are three types of SOEs: (1) wholly state-owned enterprise with the state as sole owner; (2) functioning SOEs, being state-controlling enterprises with many shareholders, but where the state retains overwhelming 
control; and (3) those in which the state owns shares, but not enough to control the firm. In the survey, we define only the first two types as state-owned enterprises (SOE).

Family Ownership: Despite substantial inquiry [56], there is still no agreement on a single encompassing description of a family firm [57]. However, three broad definitions are evident in the literature [58]. The first consists of family-owned and managed firms, where family ownership is at least 50 percent and the family is actively involved in management or governance. The second is narrower and usually consists of large listed companies with a family ownership threshold of at least 5 percent, usually accompanied by family control or family members as board members. The final definition of a family firm is one in which the founder or a member of his/her family, by either blood or marriage, is an executive, director, or blockholder [59], [60]. In the survey, the first of these definitions is adopted, that is, a family which have a $50 \%$ or more share of a firm and a family member is involved into the firm's management is defined as a family firm.

Firm-level Innovation: When studying firm-level innovation, researchers normally have three subsequent measurement of innovation, that is, innovation inputs, innovation activities, and innovation outputs. Innovation input is often defined and measured as a firm's financial investment that is dedicated towards the exploration and exploitation of new opportunities, such as R\&D expenditure, R\&D intensity [61], [62]. In an often lengthy and complex innovation process [63], innovation input transforms into innovation outputin the form of, for instance, patented knowledge or newly developed products [64]. Thus, the innovation process or capabilities are used to measure as innovation activities [65], [66]. In this paper, we employ the innovation input, i.e. R\&D intensity as measurement of firm-level innovation.

3) Control Variables: We employ two set of control variables: over the firm's current operational characteristics and over financing characteristics. The operational variables are as follows: 
We use the variable Family_member (three or more family members involved in the firm's management) to control for the potential conflicts of family members in a family firm (see [67]). Risk-preference (the firm is not averse to high risk) is a proxy for business objectives. Given SMEs can be very different from large firms in terms of business operations [68]. For example, "Mum-and-Dad" SMEs do not typically pursue a high-growth thus a high-risk strategy [69]. Instead, the owners of SMEs like these may merely enjoy operating the SME itself [70].

Firm year (the number of years since establishment) is an important proxy for SME life cycle. Firm age largely corresponds to the business cycle of SMEs. Start-up and early-stage SMEs may then resort to external equity, particularly private investors, and business angels [69]. One reason is the restrictions in internal equity. At the starting stage of a SME, retained profits are scarce, and the personal sources of the owner and firm-connections are very limited. A second reason is associated with a combination of information asymmetries and potential agency problems related to the lack of a trading history. The lack of collateralizable assets can exacerbate the problem of restricted access to finance [71]. From this perspective, firm age positively relates to external finance seeking. However, as SMEs move from the start-up or earlystage to the middle-stage, they can source more finance from retained profits. SMEs can then replace external equity with internal equity.

Growth (yearly sales have grown) represent a major sign of creditworthiness for SMEs. Pecking order theory suggests that a firm will tap into internal funding first, whereas trade-off theory supposes that a profitable firm gives more ground to the use of tax shields. Profitability is then a key benchmark for a firm's performance, thus helping in improved acceptance of finance applications. Being conssistant with previous work [72]. 
Assets (total assets) can also influence access to finance by SMEs. First, the informational asymmetry between insiders and outsiders can be more severe in small firms because there is less information in the market about smaller firms [73]. Therefore, smaller firms seek proportionately less debt. Second, profitability positively relates to firm size [74]. Therefore, trade-off theory predicts that larger firms should seek more debt to benefit from the tax shields, though pecking order theory would predict that larger firms use more debt. Third, tax considerations could be of less concern for SMEs because they are less likely to generate large profits and therefore less likely to use debt for tax shield purposes [75]. If this is the case, size can be negatively associated with debt. In addition, given there is a positive relationship between size and age, start-up or early stage SMEs are more likely to seek equity.

Export (if the firm exports) can be associated with growth ambition [76]. Therefore, we expect exporter SMEs to seek more funds compared with non-exporter SMEs. However, exporter SMEs bear more risk because of more rapid growth and market uncertainty. Therefore, exporter SMEs are more likely to have loan applications turned down compared with their non-exporter counterparts [77].

Industry is suggested by several studies indicating the important influence of industry on firm financing patterns [78], [79]. For example, Ballakishnan and Fox [78] find that firm effects explain 52\% of capital structure variation and inter-industry differences another 11\%, while Degryse et al.[79] find that industries display diverse average debt levels. The trade-off theory also implies that there could be an optimal leverage ratio in an industry at which SMEs are targeted. Alternatively, one explanation given by Myers' [80] "modified pecking order" theory is that we can consider industry as a proxy for several influential factors, including asset structure, asset risk, and operating characteristics. For example, Degryse et al.[79] find that SMEs in the retail trade non-food and food industries display higher debt ratios. In addition, Degryse et al. [79] suggest that the pecking order theory dominates the wholesale trade, retail trade food and non-food, and 
transport sectors, whereas, the trade-off theory dominates the catering and leisure sectors. Van der Wijst [81] likewise concludes that the manufacturing industry is capital intensive and requires large investments in fixed assets derived from both debt and equity while the retail sector needs relatively less short-term debt.

The control variables for SME financing comprise:

Internal_finance, External_debt and External_equity (reliance on internal finance or external debt/equity) which are the three sources for SME financing include retained profits or (new) equity, bank loans or other debt contracts. Brown et al [42] suggest that equity finance, in general, has advantages over debt finance for Hi-tech small firms, because: 1) there are no collateral requirements; 2) additional equity does not magnify problems associated with financial distress. 3) internal equity finance does not create adverse selection problems. However, given that most SMEs have very limited capacity to access equity markets, especially in less developed financial markets such as in China, debt finance is still the major financing source for SMEs. However, Brown [42] suggest that there are several negative factors affecting hi-tech SMEs' obtaining debt finance. First, the structure of a debt contract is not well suited for R\&D-intensive firms with uncertain and volatile returns [82]. Second, adverse selection problems [14] are more likely in high-tech industries due to the inherent riskiness of investments. Third, debt financing can lead to ex post changes in behavior (moral hazard) that are likely more severe for high-tech firms because they can more easily substitute high-risk for low-risk projects. Fourth, the expected marginal cost of financial distress rises rapidly with leverage for young high-tech firms because their market value depends heavily on future growth options that rapidly depreciate if they face financial distress [83].

Collateral (where collateral lending is the major way for the firm to borrow) follows from the informational advantages of borrowers over lenders. That is, collateral is used to offset the problems of 
adverse selection [84] and/or moral hazard [85] caused by information asymmetry. In these situations, information asymmetry gives rise to greater collateral and thus higher borrowing costs (e.g. [86], [60]). In particular risky firms typically must pledge collateral to obtain debt finance [87].

National_bank, Local_bank and Non-bank (relationship is with a national/local/nonbank bank) represent the characteristics of SMEs' relationship banks. One unique feature of China's banking industry is that majority of the banking assets are under the control of the Chinese Government [88]. Brandt and Li [30] and Ge and Qiu [31] find that Chinese state-owned banks are more likely to provide loans to SOEs due to political concerns, such as improving the employment rate and enhancing social stability. State-owned banks only seek to maximize their risk-adjusted returns when they offer loans to non-SOEs. Since the banks have different incentives when they lend to SOEs and non-SOEs, the homogeneity of banks can have a substantial influence on SME finance.

Bank_year (length of borrower relationship with banks) is a major measurement of relationship banking in the literature (e.g. [89], [90]). Relationship lending technologies assign a key role to soft information, qualitative information obtained via personal interaction/acquaintance and that is difficult to codify [89].

Lastly, Government_fund (the numbers of government subsidies or grants received by SME for innovation) represents the government support for $R \& D$. In China, $R \& D$ activities obtained a larger prominence in economic policy [51]. Deng and Hu [91] find that an increase in the amount and the continuity of R\&D investments as well as in the number of patent applications indicates increasing effectiveness of policy measures after 2006 .

\section{Models}


To solve the selection as well as potential endogenous issue, following Ghoul et al [92] and Wooldridge [93], we employ Heckman selection estimation procedures in this paper. We first specify a probit model for Eq. 1 as follows, where Finance_apply measures whether the firm apply for finance in the survey year. Family and State are dummy variables for the ownerships; R\&D_intensity is the ratio of R\&D expenditure to total sales; and Finance_difficulty is a proxy for the financial constraints faced by SMEs deriving from the survey question, "to what extent the firm has a difficulty in financing (1: "extremely easily"; 7 : “extremely hard”). All other variables are as before.

$$
\begin{aligned}
& \text { Finance_apply }=\alpha_{0}+\alpha_{1} \text { Famil }+\alpha_{2} \text { State }+\alpha_{3} R \& D_{-} \text {intensity }+\alpha_{4} \text { Finance_difficulty } \\
& +\alpha_{5} \text { Family_member }+\alpha_{6} \text { Firm_year }+\alpha_{7} \text { Growth }+\alpha_{8} \text { Assets }+\alpha_{9} \text { Export } \\
& +\alpha_{10} \text { Risk_preference }+\alpha_{11} \text { External_debt }+\alpha_{12} \text { External_equity } \\
& +\alpha_{13} \text { National_bank }+\alpha_{14} \text { Local_bank }+\alpha_{15} \text { Non_bank }+\alpha_{16} \text { Export } \\
& +\alpha_{17} \text { Gov_fund }+\alpha_{18} \text { Industry }+\varepsilon
\end{aligned}
$$

Then in the second stage, we regress the dependent variable of FinTech_finance deriving from the survey question, "to what extent the firm seeks FinTech finance (1: extremely least; 7: extremely most)" on the inverse Mills' ratio $(\lambda)$ estimated from the first stage, along with the variable of interest and the control variables as follows of Eq. 2, where FinTech_Finance measures the firm's FinTech finance in the survey year. Invmills is the inverse Mills' ratio $(\lambda)$ estimated from Eq.1. All the other variables are the same as those in Eq.1.

$$
\begin{aligned}
& \text { Fintech_finance }=\alpha_{0}+\alpha_{1} \text { Famil }+\alpha_{2} \text { State }+\alpha_{3} R \& D \text { Dintensity }+\alpha_{4} \text { Finance_difficulty } \\
&+\alpha_{5} \text { Family_member }+\alpha_{6} \text { Firm_year }+\alpha_{7} \text { Growth }+\alpha_{8} \text { Assets }+\alpha_{9} \text { Export } \\
&+\alpha_{10} \text { Risk_preference }+\alpha_{11} \text { External_debt }+\alpha_{12} \text { External_equity } \\
&+\alpha_{13} \text { National_bank }+\alpha_{14} \text { Local_bank }+\alpha_{15} \text { Non_bank }+\alpha_{16} \text { Export } \\
&+\alpha_{17} \text { Gov_fund }+\alpha_{18} \text { Industry }+\alpha_{19} \text { Finance_apply }+\alpha_{20} \text { invmills }+\varepsilon
\end{aligned}
$$

\section{Empirical results}

\section{A. Univariate analysis}


In Table 2, we report univariate tests of differences in means between state-owned and non-state-owned firms, and family and non-family firms. State-owned and family firms account for $2.9 \%$ and $32.9 \%$ of the sample firms, among which a number of variables show a significant difference in means especially for stateowned firms. Firstly, state-owned firms are significantly less likely to seek FinTech finance than would nonstate-owned firms. By contrast, family firms do not show a significant difference in seeking FinTech finance when compared with non-family firms. However, both state-owned firms and family firms do not have a significant difference in the attitude towards financing difficulties. Second, as expected, family firms show a lower level of R\&D intensity than non-family firms; whereas, state-owned firms show a higher level of R\&D intensity than do non-state-owned firms. Third, for the control variables, state-owned firms seem to be more mature in terms of firm age. Both state-owned and family firms have a longer relationship with relationship banks as compared with their counterparts. However, both of them are less likely to export. Regarding the financing behaviors, state-owned firms are more likely to rely on external equity, but less likely to rely on internal finance and external debt. By contrast, family firms are more likely to rely on internal finance. In addition, state-owned firms are more likely have a local bank as relationship bank, but less likely to have a national bank. Lastly, unsurprisingly, state-owned firms more benefit from government subsidies and grants than non-state-owned firms do. However, univariate analysis does not control for other variables that could affect firms' innovative behaviors. To confirm the hypotheses, we conduct multivariate analysis.

\author{
$<$ INSERT TABLE 2 HERE $>$
}

\title{
B. Multivariate analysis
}


Before regression estimation, we conduct a verification test for multicollinearity problem. As shown in Table 3, most of correlation values are well below 0.3 , except for the correlation between national banks and local banks (0.685), as well as external debt and collateral (0.323). For the former, this may result from the closer relationship between national banks and some of local banks, because a number of local banks have expanded their markets into wider regions. For the latter, the close relation between collateral and external debt is in line with the fact that SMEs are heavily rely on collateralized lending. Again, the close relation between local banks and non-bank financial institutions (0.289) are also due to the expansion of the local banks in terms of banking businesses and markets. In addition, the high correlation between R\&D intensity and government subsidies (0.281) may imply an effectiveness of government support for innovation. Then, larger firms are positively correlated (correlation coefficient in brackets) with finance application (0.234); Family SMEs would like to make use of international finance as well as collateral (0.231); and some of family firms have more than three members involved into management (0.231).

\section{$<$ INSERT TABLE 3 HERE $>$}

We calculate further the values of variance inflation factor (VIF) for the independent variables (Table 4). The results show that all the VIF values are well below three.

\section{$<$ INSERT TABLE 4 HERE $>$}

1) State-owned Firms, FinTech Finance and Innovation: The results in Table 5 are for the relationship between state ownership, FinTech finance, and innovation. The results in Columns 1 and 2 are for a probit model, which acts as the first-stage model in Heckman procedures; Columns 3-6 show the estimation results of the Heckman models discussed in Section 3. Columns 3 and 4 show the results of the effects of state 
ownership on FinTech finance; Columns 5 and 6 show results of the models for testing the interaction between state ownership and innovation.

\section{$<$ INSERT TABLE 5 HERE $>$}

In the results in Column 1, we do not find state-owned firms or family firms have any significant difference in applying for finance in the survey year. However, we find that R\&D intensity, assets, growth, exports, finance difficulty, external debt, national bank, non-bank and collateral are all significantly correlated with finance apply. In specific, the firms with R\&D are $1.9 \%$ more likely to apply finance. This is in line with the findings in the literature [10]. We interpret the positive relations between sales growth, firm assets, and finance application as the creditworthiness of profitable firms. Then the positive effects of export on the finance application is well in line with the literature (see Section 3). With respect to financing aspects, the firms that claims for financing difficulty, however, are more likely to apply for finance with marginal effects of $2.4 \%$. The firms that rely on external debt are $14.3 \%$ more likely to apply for finance. Interestingly, firms whose relationship banks are national banks or/and non-bank financial institutions are more likely $(9.8 \%$ and $14.5 \%$, respectively) to apply for finance. This may imply that, on the one hand, national banks and nonbank financial institutions are more "friendly" towards SMEs. On the other hand, the local banks normally controlled by the local governments may take the directives of local authorities to allocate funds or loans. Lastly, we find that collateral is an effective factor behind lending.

Columns 3 and 4 report that state-owned firms are much less (odds ratio is $38.7 \%$ ) likely to seek FinTech finance when compared with non-state-owned firms. This gives evidence for Hypothesis 2 . We also find that the firms with financial constraints (see Finance_difficulty) are much more likely to seek FinTech finance with odds ratio of 1.714. This means that given the other variables are constant, the odds of high levels of 
FinTech financing versus the combined middle and low levels of FinTech finance are 1.714 times greater for financially constrained firms. Put differently, for a more financial-constrained firm, the chances of high level of their FinTech financing are 1.714 times greater than for a less financially constrained firm. This supports Hypothesis 1, that is, SMEs with more severe financial constraints are more likely to seek FinTech finance. Thus, we conclude that state-owned firms may have better access to credit in state-owned banks thus may suffer less financial constraints than non-state-owned banks (e.g. [27], [28]), though the differences in financial difficulty of univariate analysis is not significant. Another reason for less FinTech-financing is that a firm with a high state ownership does not need to hold high level of cash since credit will be readily available from state-owned banks, even if the company becomes financially distressed and loses access to external private funding [9].

Then, we check the connection between state ownership, innovation, and FinTech finance in Columns 5 and 6, where we add the interaction item between state ownership and R\&D intensity to the model. The results show that state ownership does not have a significant influence on the relationship between R\&D intensity and FinTech finance. Though state -owned firms showed a significant high level of R\&D intensity than non-state-owned firms in the results of univariate analysis of Table 2, state-owned firms are not found particularly to seek FinTech to finance R\&D activities. This implies that, more R\&D activities for stateowned firms does not lead to higher levels of FinTech finance seeking; however, the results of multivariate analysis fail to support Hypothesis 4c in any way.

2) Family Firms, FinTech Finance and Innovation: Table 6 reports the results of the relationship between family ownership, FinTech finance, and innovation. Columns 1 and 2 show the results of the effects of family ownership on FinTech finance; Columns 3 and 4 show results of the models for testing the interaction between state ownership and innovation. Then Columns 5 and 6 adopt state ownership as a control variable. 
In Column 1 and 2, family firms are significantly less (odds ratio: 78.7\%) likely to seek FinTech finance when compared with non-family firms. This supports for Hypothesis 3. In addition, we also find that higher degree of family control over the family firms proxied by the more family members (three or more) getting involved into management further reduce the chances of seeking FinTech finance with odds ratio of $69.7 \%$. This is interpreted by the proposition that family firms prefer internal financing (either from equity contributions by family shareholders or retained earnings) to external financing [94], [46], which is also proved by the results of univariate analysis in Table 2 .

\section{$<$ INSERT TABLE 6 HERE $>$}

Furthermore, Columns 3 and 4 reports that family ownership has a significant and positive effect on the relation between R\&D intensity and FinTech finance with an odds ratio of 4.913. This says that for an innovative family firm, the likelihood of a higher degree of FinTech financing is 4.913 times greater than for a less innovative firm. In other words, family firms are more likely particularly to seek FinTech to finance R\&D activities, which give evidence for Hypothesis $4 \mathrm{~b}$. To check the robustness of this finding, we also add state ownership to the models as a control variable, and the results are in Columns 5 and 6 . Both family and state ownership still have a significantly negative effect on FinTech finance; moreover, family firms have a greater chance of seeking FinTech finance to support R\&D expenditure. However, there is a puzzling negative relation between R\&D intensity and FinTech finance in these models. In summary, the effects of R\&D intensity on FinTech finance is not consistent across the models. Thus, we do find sound evidence for supporting Hypothesis 4a in this paper.

3) Determinants of FinTech finance: For the control variables, as discussed above, we find that the firms that claim for more severe financial constraints are more active in seeking on-line lending i.e. FinTech 
finance serves as a financing source. The results are consistent with the results of the model for firm finance seeking in Columns 1 and 2 in Table 5. This implies that FinTech acts as an alternative financing source because financial constrained firms are unable to get finance elsewhere. As evidence, state-owned firms and family firms are not so keen on using on-line lending as their counterparts. The former has their advantages of getting finance from government-controlled banks; the latter may be inclined to rely more on internal finance. In this sense, a SME seems to be compelled to have a go on FinTech finance because of financial problems. Interestingly and surprisingly, we also find another two consistent and significant variables nonbank and bank_year across all the models. The firms whose relationship banks are non-bank financial institutions are less active in using FinTech finance with an odds ratio of 30.2-49.2\%. As discussed above, non-stat-owned firms are less likely to get finance form state-owned banks; thus, non-state-owned firms may rely more on non-bank financial institutions or non-bank financing sources. In other words, to some extent online finance may act as an alternative non-bank financing source. The negative relationship between nonbank and FinTech finance can imply that online finance, at this stage, may only act as a complementary financing source for non-bank finance. By contrast, the positive effects of bank_year on FinTech finance may imply a "lock in" problem for SMEs. That is, some SMEs face higher switching costs due to weak bargaining power with their relationship banks [95]. In our another forthcoming paper based on the same dataset, we actually find that bank_year has a significant and positive effect on SMEs' financing costs. This may suggest that, for SMEs, FinTech finance are rather acting as a complementary financing source than an "attractive" and a MUST financing source.

Interestingly, the firms that rely on external debt probably prefer not to use FinTech finance. However, the results are not significant for the models with an independent variable of state ownership. By contrast, the firms that rely on external equity probably prefer to use FinTech finance. However, the results are not 
significant for the models with an independent variable of family ownership. This can be interpreted by the cost of capital, because, general speaking, external equity is costlier that external equity. Thus, the results imply that the cost of FinTech finance is well between cost of external debt and cost of external equity. As discussed above, Brown et al [42] suggest that equity finance may have advantages over debt finance for hitech small firms, because: 1) there are no collateral requirements; 2) additional equity does not magnify problems associated with financial distress; 3) internal equity finance does not create adverse selection problems.

However, other than state-owned SMEs, Chinese SMEs generally have very limited capacity to access equity markets. This is because, in theory, the owners of the state-owned SMEs are governments; thus, they have much more chances of getting capital injection from the governments or their controlled agents. Nevertheless, for private Chinese SMEs with financial constraints especially family-owned firms, there is very little or no chance of attaining such less-costly equity injections. For the remaining control variables, the results are more complex and inconsistent, because FinTech itself as financing source is still under developing.

\section{Concluding remarks}

Motivated by dramatically rapid development of FinTech and long-standing SMEs' financing problem, this paper aimed to investigate the relations between firm ownership, innovation, and FinTech finance. Using a sample of Chinese hi-tech SMEs, we find that firm ownership has a significant influence on FinTech finance. In specific, both state owned and family firms are less likely to seek FinTech finance with odds ratios of $38.7 \%$ and $78.7 \%$ respectively. In the meantime, we find that the firms with financial constraints are much more likely to seek FinTech finance with odds ratio of 1.714. We conclude that state-owned firms 
may have better access to credit in state-owned banks thus may suffer less financial constraints than nonstate-owned banks. Another reason for less FinTech-financing is that a firm with a high state ownership does not need to hold high level of cash since credit will be readily available from state-owned banks, even if the company becomes financially distressed and loses access to external private funding.

The less seeking FinTech finance for family firms is interpreted by the proposition that family firms prefer internal financing (either from equity contributions by family shareholders or retained earnings) to external financing. We also find that more R\&D activities for state-owned firms does not lead to higher levels of FinTech finance seeking; however, family ownership has a significant and positive effect on the relation between $R \& D$ intensity and FinTech finance with an odds ratio of 4.913 . This says that family firms are more likely particularly to seek FinTech to finance R\&D activities.

Regarding other factors affecting FinTech finance, we find that, the firms whose relationship banks are non-bank financial institutions are less active in using FinTech finance with an odds ratio of 30.2-49.2\%; at the same time, the firms that have a longer length of relationship banking are more likely to use FinTech finance with an odds ratio of $149.3-186.0 \%$. This suggests that FinTech finance, at this stage, may act as rather a complementary financing source than a competing financing source. . Particularly, we find the evidence that, the owners of the state-owned SMEs are governments; thus, they have much more chances of getting capital injection from the governments or their controlled agents. However, for private Chinese SMEs with financial constraints, especially family-owned firms, they is very little or no chance of receiving such low-cost equity injections.

\section{References}

[1] G. Dorfleitner, L. Hornuf, M. Schmitt, and M. Weber, FinTech in Germany, Springer International Publishing, https://doi.org/10.1007/978-3-319-54666-7, 2017. 
[2] X. Zhu, "Understanding China's growth: past, present and future,” Journal of Economic Perspectives. ,vol. 26, no. 4, pp.103$124,2012$.

[3] M. Boycko, A. Shleifer, and R.W. Vishny, “A theory of privatization,” The Economic Journal., vol. 106, no.435, pp. 309-319, 1996.

[4] W. Megginson, J.Netter, "From state to market: A survey of empirical studies on privatization," Journal of Economics Literature., vol.39, no.2, pp.321-389, 2001.

[5] J. Kornai, "Resource-constrained versus demand-constrained systems," Econometrica., vol.47, no.4, pp. 801-819, 1979.

[6] J. Kornai, Economics of Shortage., Amsterdam: North-Holland Pub. Co, 1980

[7] F. Allen, J. Qian, and M. Qian, “Law, finance, and economic growth in China,” Journal of Financial Economics., vol. 77, no. 1 pp. 57-116, 2005.

[8] M. C. Jensen, W. H. Meckling, "Theory of the firm: Managerial behavior, agency costs and ownership structure," Journal of Financial Economics., vol. 3, no. 4, pp. 305-360, 1976.

[9] W. Megginson, B. Ullah, and Z. Wei, "State ownership, soft-budget constraints, and cash holdings: Evidence from China's privatized firms," Journal of Banking \& Finance., vol. 48, no. C, pp. 276-291, 2014.

[10] T. Beck, A. Demirguc-Kunt, and V. Maksimovic, "Financing patterns around the world: Are small firms different?" Journal of Financial Economics., vol. 89, no. 3, pp. 467-487, 2008.

[11] J. A. Schumpeter, The theory of economic development., Cambridge, MA: Harvard University Press, 1934.

[12] K. Arrow, "Economic Welfare and the Allocation of Resources for Invention" (pp. 609-625), in R. R. Nelson (Ed.), The Rate and Direction of Inventive Activity: Economic and Social Factors (Princeton, NJ: Princeton University Press, 1962.

[13] R. Pindyck, "Irreversibility, uncertainty, and investment," Journal of Economic Literature., vol. 29, no. 3, pp. 1110-1148, 1991.

[14] J. Stiglitz, A. Weiss, "Credit rationing in markets with imperfect information, ”American Economic Review., vol. 71, no. 3, pp. 393-410, 1981.

[15] P. Himmelberg, B. Petersen, "R \& D and Internal Finance: A Panel Study of Small Firms in High-Tech Industries," The Review of Economics and Statistics., Vol. 76, No. 1, pp. 38-51, 1994.

[16] R. Carpenter, B. Petersen, "Capital market imperfections, high-tech investment, and new equity financing," The Economic Journal., vol. 112, no. 477, pp. 54-72, 2002.

[17] M. Fenwick, J.A. McCahery, and E. P. M. Vermeulen, FinTech and the Financing of Entrepreneurs: From Crowdfunding to Marketplace Lending. Social Science Electronic Publishing, 2017.

[18] A. Schwienbacher, B. Larralde, Crowdfunding of small entrepreneurial ventures. Social Science Electronic Publishing, 2010.

[19] L. Hornuf, A. Schwienbacher, Crowdinvesting-Angel investing for the masses? Social Science Electronic Publishing, 2014.

[20] E. Mollick, “The dynamics of crowdfunding: an exploratory study,” Journal of Business Venturing., vol. 29, no. 1, pp.1-16, 2014.

[21] J. Hemer, “A snapshot on crowdfunding,” Working Paper Series: Firms and Region, 2011. 
[22] A. Schwienbacher, Financing the business. In: T. Baker, F. Welter, (eds.) The Routledge Companion to Entrepreneurship. Routledge, London, 2013.

[23] H. Hakenes, F. Schlegel, Exploiting the Financial Wisdom of the Crowd -- Crowdfunding as a Tool to Aggregate Vague Information," SSRN Electronic Journal, 2014.

[24] R. P. Larrick, R. L.Keeney, and J. B. Soll,. Better metrics for energy decisions. INFORMS, Charlotte, 2011.

[25] T. Balyuk, Financial Innovation and Borrowers: Evidence from Peer-to-Peer Lending, Social Science Electronic Publishing, 2016.

[26] F. Allen, D.Gale, “Optimal Financial Crises,” The Journal of Finance, vol. 53, no. 4, pp. 1245-1284, 1998

[27] J.Y. Lin, G. Tan, "Policy burdens, accountability, and the soft budget constraint," The American Economic Review., vol. 89, no. 2, pp.426-431, 1999.

[28] R. Cull, L. Xu, "Bureaucrats, state banks, and the efficiency of credit allocation: the experience of Chinese state-owned enterprises," Journal of Comparative Economics., vol. 28, no. 1, pp. 1-31, 2000.

[29] R. Cull, L. Xu, "Who gets credit? The behavior of bureaucrats and state banks in allocating credit to Chinese state-owned enterprises," Journal of Development Economics., vol. 71, no. 2, pp. 533-559, 2003.

[30] L. Brandt, H. B. Li, "Bank discrimination in transition economies: Ideology, information or incentives?" Journal of Comparative Economics., vol. 31, no. 3, pp. 387-413, 2003.

[31] Y. Ge, J. P. Qiu, "Financial development, bank discrimination, and trade credit," Journal of Banking and Finance., vol. 31, no. 2, pp. 513-530,2007.

[32] J. J. Chrisman, J. H. Chua, and R. A. Litz, "Comparing the agency costs of family and non-family firms: Conceptual issues and exploratory evidence," Entrepreneurship: Theory \& Practice., vol. 28, no. 4, pp. 335-354, 2004.

[33] J. H. Davis, F. D. Schoorman, , and R. Donaldson, “Toward a stewardship theory of management," Academy of Management Review., vol. 22, no. 1, pp. 20-47, 1997.

[34] I. Le Breton-Miller, D. Miller, "Why do some family businesses out-compete?" Governance, Long-term orientations, and sustainable capability," Entrep Theory Pract., vol. 30,no. 6,pp. 731-746, 2006

[35] J. J. Chrisman, J. H.Chua, F. W. Kellermanns, , and E. P. Chang, “Are family managers agents or stewards?” An exploratory study in privately held family firms," Journal of Business Research., vol. 60, no. 10, pp. 1030-1038, 2007.

[36] Y. Kim, X. Li, and F. Y.Gao, “Does family involvement increase business performance? Family-longevity goals'moderating role in Chinese family firms," Journal of Business Research., vol. 66, no. 2, pp. 265-274, 2013.

[37] TM Zellwegerx, FW Kellermanns, KA Eddleston, E Memili, "Building a family firm image: how family firms capitalize on their family ties.” Journal of Family Business Strategy., vol. 3, no. 4, pp. 239-250, 2012

[38] P. Westhead, D. Storey, "Financial constraints on the growth of high technology small firms in the United Kingdom," Applied Financial Economics., vol. 7, no. 2, pp. 197-201, 1997.

[39] A. Goodacre and I. Tonks, Finance and technological change. In P. Stoneman (Ed.), Handbook of the economics of innovation and technological change (pp. 298-341). Oxford: Blackwells, 1995. 
[40] D. Storey, B. Tether, "New technology-based firms in the European Union: An introduction," Research Policy., vol. 26, no 9, pp. 933-946, 1998.

[41] M. G. Colombo, L. Grilli, “On growth drivers of high-tech start-ups: Exploring the role of founders' human capital and venture capital," Journal of Business Venturing., vol. 25, no. 6, pp. 610-626, 2010.

[42] J.R. Brown, S. M. FAZZARI, B. C. Petersen, "Financing Innovation and Growth: Cash Flow, External Equity, and the 1990s R\&D Boom," The Journal of Finance., vol. 64, no. 1, pp. 151-185, 2009.

[43] B. H. Hall, “The financing of research and development," Oxford Review of Economic Policy, vol. 18, no. 1, pp. 35-51, 2002.

[44] S. Bond, D. Harhoff, J. Van Reenen, "Investment, R\&D and Financial Constraints in Britain and Germany," Annales Déconomie Et De Statistique., vol. 79/80, pp. 433-460, 2003.

[45] A. Hamelin, "Small business groups enhance performance and promote stability, not expropriation. Evidence from French SMEs, ” Journal of Banking \& Finance., vol. 35, no. 3, pp. 613-626, 2011.

[46] J Lappalainen and M Niskanen, "Behavior and attitudes of small family firms towards different funding sources," J Small Bus Entrep., vol. 26, pp. 579-599, 2013.

[47] E Croci, JA Doukas and H Gonenc, "Family control and financing decisions,". European Financial Management., vol. 17, no. 5, pp. 860-897, 2011.

[48] P Gottardo and AM Moisello, “The capital structure choices of family firms," Management Finance., vol. 40, no. 3, pp. 254$275,2014$.

[49] J. Liu, H. Wang, C. Hui and C. Lee, "Psychological ownership: how having control matters," Journal of Management Studies., vol. 49, no. 5, pp. 869-895, 2012.

[50] A. Zhang, Y. Zhang, and R. Zhao, "A study of the R\&D efficiency and productivity of Chinese firms," Journal of Comparative Economics., vol. 31, pp. 444-464, 2003.

[51] P. Boeing, F. Muellerb and P Sandner, "China's R\&D explosion—Analyzing productivity effects across ownership types and over time," Research Policy., vol. 45, pp. 159-176, 2016.

[52] J. Mairesse and P Mohnen, “Accounting for Innovation and Measuring Innovativeness: An Illustrative Framework and an Application," American Economic Review., vol. 92, no. 2, pp. 226-230, 2012.

[53] R. Donckels and E. Fröhlich, “Are Family Businesses Really Different? European Experiences from STRATOS,” Family Business Review., vol. 4, no. 2, pp. 149-160, 1991.

[54] R. Garnaut, L. Song, S. Tenev and Y. Yao, “China's Ownership Transformation: Process, Outcomes, Prospects,” Washington, DC: The International Finance Corporation and the International Bank for Reconstruction and Development, 2005.

[55] S. J. Chang and S. Y Jin, "The performance of state owned enterprises in China: An empirical analysis of ownership control through SASACs," Institute of Management Accountants., 2016.

[56] J Xi, S Kraus, M Filser, FW Kellermanns, "Mapping the field of family business research: past trends and future directions," Int Entrep Manag J., vol. 11, no. 1, pp. 113-132, 2015.

[57] H Harms, "Review of family business definitions: cluster approach and implications of heterogeneous application for family business research," Int J Financ Stud., vol. 2, no. 3, pp. 280-314, 2014. 
[58] M Sageder, C Mitter, and B Feldbauer-Durstmuller, "Image and reputation of family firms: a systematic literature review of the state of research," Rev Manag Sci., vol. 12, pp. 1-43, 2016.

[59] R. C. Anderson and D. M. Reed, "Founding-family ownership and firm performance: Evidence from the S\&P 300,” Journal of Finance., vol. 58, no. 3, pp. 1301-1328, 2003.

[60] X. Pan and GG. Tian, "Family control and loan collateral: Evidence from China," Journal of Banking \& Finance., vol. 67, pp. 53-68, 2016.

[61] JH. Block, D. Miller, P. Jaskiewicz and F. Spiegel, "Economic and technological importance of innovations in large family and founder firms: an analysis of patent data," Family Business Review., vol. 26, no. 2, pp. 180-199, 2013.

[62] H.-L. Chen and W.-T. Hsu, "Family ownership, board independence, and R\&D investment," Family Business Review., vol. 22 , no. 4, pp. 347-362, 2009.

[63] R. Garud, P. Tuertscher and A. H. Van de Ven, "Perspectives on innovation processes," Academy of Management Annals., vol.7, no.1, pp.775-819, 2013.

[64] C. Schmiedeberg, "Complementarities of innovation activities: An empirical analysis of the German manufacturing sector," Research Policy., vol. 37, no. 9, pp. 1492-1503, 2008.

[65] L. Cassia, A. De Massis and E. Pizzurno, "Strategic innovation and new product development in family firms: An empirically grounded theoretical framework," International Journal of Entrepreneurial Behaviour \& Research., vol. 18, pp. 198-232, 2012.

[66] L. C. Hsu and H. C. Chang, "The role of behavioral strategic controls in family firm innovation," Industry and Innovation., vol. 18, no. 7, pp. 709-727, 2011.

[67] M. Cheng, B. Lin and M Wei, "Executive compensation in family firms: The effect of multiple family members," Journal of Corporate Finance., vol. 32, pp. 238-257, 2015.

[68] J. Ang, "Small business uniqueness and the theory of financial management," Journal of Small Business Finance., vol. 37, no. 1, pp. 219-226, 1991.

[69] A.N. Berger and G. F. Udell, "The economics of small business finance: The roles of private equity and debt markets in the financial growth cycle," Journal of Banking \& Finance., vol. 22, no. 6-8, pp. 613-673, 1998.

[70] E. Vos, A. J. Y. Yeh, S. Carter and S. Tagg, “The happy story of small business financing," Journal of Banking \& Finance., vol. 31, no. 9, pp. 2648-2672, 2007.

[71] C.M.A. Bhaird, and B. Lucey, "Determinants of capital structure in Irish SMEs,” Small Business Economics., Vol. 35 No. 3 , pp. 357-375, 2010.

[72] D. Allen, “The pecking order hypothesis: Australian evidence," Applied Financial Economics., vol. 3, no. 2, pp. 101-112, 1993.

[73] M Pasillaki and N. Daskalakis, “Are the determinants of capital structure country or firm specific?" Small Business Economics., vol. 33, no. 3, pp. 319-333, 2009.

[74] Z.S. Serrasqueiro, and P.M. Nunes, "Performance and size: Empirical evidence from Portuguese SMEs," Small Business Economics., vol. 31 no. 2: pp. 195-217, 2008.

[75] R Pettit and R Singer, "Small business finance: A research agenda,” Financial Management., vol. 14, no. 3, pp. 47-60, 1985. [30] 
[76] SA Zahra, D Neubaum and M Huse, "Entrepreneurship in medium-size companies: Exploring the effects ownership and governance systems," Journal of Management., vol. 26, no. 5, pp. 947-976, 2000.

[77] A Riding, BJ Orser, M Spence and B Belanger, "Financing new venture exporters," Small Business Economics.,vol. 38, no. 2, pp. 147-163, 2012.

[78] S Balakrishnan and I Fox , “Asset specificity, firm heterogeneity and capital structure,” Strategic Management Journal., vol. 14, no. 1, pp. 3-16, 1993.

[79] H Degryse, PD Goeij and P Kappert, “The impact of firm and industry characteristics on small firms' capital structure,” Small Business Economics., vol. 38, no. 4, pp. 431-447, 2010.

[80] S. C.Myers, “Determinants of corporate borrowing,” Journal of Financial Economics., vol. 5, pp. 147-175, 1977.

[81] D. Van der Wijst, Financial Structure in Small Business: Theory, Tests and Applications. Berlin: Springer-Verlag, 1989.

[82] J. Stiglitz, “Credit Markets and the Control of Capital,” Journal of Money, Credit and Banking., vol.17, pp.393-410, 1985.

[83] Cornell, Bradford, and Alan C. Shapiro, "Financing corporate growth," Journal of Applied Corporate Finance., vol. 1, pp. $6-22,1988$.

[84] D. Besanko and A.V. Thakor, "Collateral and rationing: sorting equilibria in monopolistic and competitive credit markets," International Economic Review., vol. 28, no. 3, pp. 671-689, 1987.

[85] A.W.A. Boot, A.V. Thakor, G.F. Udell, "Secured lending and default risk: equilibrium analysis, policy implications and empirical results," The Economic Journal., vol. 101, no. 406, pp. 458-472, 1991.

[86] Z. Chen, G. J. Lobo, Y. Wang, and L. Yu, "Loan collateral and financial reporting conservatism: Chinese evidence," Journal of Banking and Finance., vol. 37, no. 12, pp. 4989-5006, 2013.

[87] N Berger, Allen, and Gregory F. Udell, “Collateral, loan quality, and bank risk," Journal of Monetary Economics., vol. 25, pp. 21-42, 1990.

[88] J. R. Barth, G. Jr. Caprio and R. Levine, "Bank supervision and regulation: What works best?" Journal of Financial Intermediation., vol. 13, no. 2, pp. 205-248, 2004.

[89] R.G. Rajan, "Insiders and outsiders: the choice between informed and arm's length debt," Journal of Finance., vol. 47, no. 4, pp. 1367-1400, 1992..

[90] A.N. Berger and G. F. Udell, "A more complete conceptual framework for SME finance,” Journal of Banking \& Finance., vol. 30, pp. 2945-2966, 2006.

[91] Y. Deng, A. Hu, "Does government R\&D stimulate or crowd out firm R\&D spending? Evidence from Chinese Manufacturing Industries," Mimeo., Beijing, 2014.

[92] S. E. Ghoul, O. Guedhami, H. Wang and C. C. Kwok, "Family control and corporate social responsibility," Journal of Banking and Finance., vol. 73, pp. 131-146, 2016.

[93] J. Wooldridge, Econometric Analysis of Cross Section and Panel Data, MIT Press, 2010.

[94] J López-Gracia, S Sánchez-Andújar, "Financial structure of the family business: evidence from a group of small Spanish firms," Family Business Review., vol. 20, no. 4, pp. 269-287, 2007. 
[95] J. F. Houston and S Venkataraman, "Information Revelation, Lock-In, and Bank Loan Commitments," Journal of Financial Intermediation., vol. 3, no. 4, pp. 355-378, 1994. 
Table 1 Variable definitions and descriptive statistics

\begin{tabular}{|c|c|c|c|c|c|c|}
\hline & Variable & Definition & Mean & Std. dev. & Min. & Max. \\
\hline \multirow{2}{*}{ 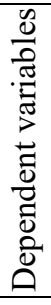 } & $\begin{array}{l}\text { FinTech_financ } \\
\text { e }\end{array}$ & $\begin{array}{l}\text { Ordinal dummy variables for to what extent the firm seek } \\
\text { FinTech finance( 1: extremely least; 7: extremely most) }\end{array}$ & 3.509 & 1.657 & 1 & 7 \\
\hline & Finance_apply & $\begin{array}{l}\text { Dummy variable with one if firm applied for finance in the } \\
\text { survey year and zero otherwise }\end{array}$ & 0.350 & 0.477 & 0 & 1 \\
\hline \multirow{3}{*}{ 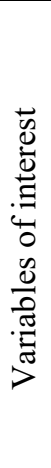 } & State-owned & $\begin{array}{l}\text { Dummy variable with one if firm is owned by the state and } \\
\text { zero otherwise }\end{array}$ & 0.029 & 0.167 & 0 & 1 \\
\hline & Family & $\begin{array}{l}\text { Dummy variable with one if family ownership more than } \\
50 \% \text { of control and zero otherwise }\end{array}$ & 0.329 & 0.470 & 0 & 1 \\
\hline & RD_intensity & $\begin{array}{l}\text { Ordinal dummy variables for the ratio of R\&D expenditure } \\
\text { to total sales: }<1 \%(1), 1 \%-3 \%(2), 3-5 \%(3), 5-10 \%(4) \text {, } \\
\text { and }>10 \%(5) \text {. }\end{array}$ & 2.361 & 1.168 & 1 & 5 \\
\hline \multirow{6}{*}{ 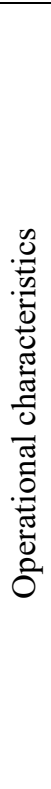 } & Family_member & $\begin{array}{l}\text { Dummy variable with one if there are two or more family } \\
\text { members involved in management and zero otherwise. }\end{array}$ & 0.522 & 0.500 & 0 & 1 \\
\hline & Risk-preference & $\begin{array}{l}\text { Dummy variable with one if the firm is not averse to high } \\
\text { risk and zero otherwise }\end{array}$ & 0.058 & 0.234 & 0 & 1 \\
\hline & Firm_year & Number of years since firm establishment & 8.207 & 6.864 & 0 & 67 \\
\hline & Growth & $\begin{array}{l}\text { Ordinal dummy variables for the sales growth rates: }<10 \% \\
\text { (1), } 10 \%-20 \% \text { (2), } 20-30 \% \text { (3), 30-40\% (4), and }>40 \% \\
\text { (5). }\end{array}$ & 1.970 & 0.842 & 1 & 5 \\
\hline & Assets & Total assets in $10,000 \mathrm{RMB}$ & 5,214 & 13,853 & 0.83 & 237,600 \\
\hline & Export & $\begin{array}{l}\text { Dummy variable with one if firm has exports and zero } \\
\text { otherwise }\end{array}$ & 0.316 & 0.465 & 0 & 1 \\
\hline \multirow{5}{*}{ 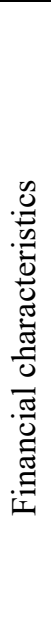 } & $\begin{array}{l}\text { Finance_difficul } \\
\text { ty }\end{array}$ & $\begin{array}{l}\text { Seven-point Likert scale from extremely easy to extremely } \\
\text { hard }\end{array}$ & 4.143 & 1.408 & 1 & 7 \\
\hline & Internal_finance & $\begin{array}{l}\text { Dummy variable with one if firm relies on internal finance } \\
\text { and zero otherwise }\end{array}$ & 0.672 & $\begin{array}{c}0.46 \\
9\end{array}$ & 0 & 1 \\
\hline & External_debt & $\begin{array}{l}\text { Dummy variable with one if firm relies on external debt } \\
\text { and zero otherwise }\end{array}$ & 0.714 & 0.452 & 0 & 1 \\
\hline & External_equity & $\begin{array}{l}\text { Dummy variable with one if firm relies on external equity } \\
\text { and zero otherwise }\end{array}$ & 0.116 & 0.321 & 0 & 1 \\
\hline & National_bank & Dummy variable with one if national bank is firm's & 0.711 & 0.454 & 0 & 1 \\
\hline
\end{tabular}




\begin{tabular}{|c|c|c|c|c|c|}
\hline Variable & Definition & Mean & Std. dev. & Min. & Max. \\
\hline & relationship bank and zero otherwise & & & & \\
\hline Local_bank & $\begin{array}{l}\text { Dummy variable with one if local bank is the firm's } \\
\text { relationship bank and zero otherwise }\end{array}$ & 0.220 & 0.415 & 0 & 1 \\
\hline Nonbank & $\begin{array}{l}\text { Dummy variable with one if nonbank financial firm is the } \\
\text { firm's relationship bank and zero otherwise }\end{array}$ & 0.051 & 0.221 & 0 & 1 \\
\hline Bank_year & $\begin{array}{l}\text { Ordinal dummy variables for the length in years of current } \\
\text { lender-borrower relationship: < } 1 \text { year }(1), 1-2 \text { years }(2), 3- \\
\text { 4years (3), 5-6 years (4), and >7 years }(5) \text {. }\end{array}$ & 2.823 & 1.112 & 1 & 5 \\
\hline Collateral & $\begin{array}{l}\text { Dummy variable with one if major loans are collateralized } \\
\text { and zero otherwise }\end{array}$ & 0.549 & 0.498 & 0 & 1 \\
\hline $\begin{array}{l}\text { Government_fu } \\
\text { nds }\end{array}$ & $\begin{array}{l}\text { Ordinal dummy variables for the number of fund } \\
\text { assistance from government: }<1(1), 1-3(2) \text {, and }>4 \text { (3). }\end{array}$ & 1.105 & 0.628 & 0 & 3 \\
\hline
\end{tabular}


Table 2 Univariate tests of means

\begin{tabular}{|c|c|c|c|c|c|c|}
\hline \multirow{3}{*}{ Variables } & \multicolumn{3}{|c|}{$\begin{array}{l}\text { State- } \\
\text { owned }\end{array}$} & \multicolumn{3}{|c|}{ Family } \\
\hline & $\begin{array}{l}\text { State } \\
\text { firms }\end{array}$ & $\begin{array}{l}\text { Non-state } \\
\text { firms }\end{array}$ & $\begin{array}{c}\text { Mean } \\
\text { difference }\end{array}$ & $\begin{array}{l}\text { Family } \\
\text { firms }\end{array}$ & $\begin{array}{l}\text { Non- } \\
\text { family } \\
\text { firms }\end{array}$ & $\begin{array}{c}\text { Mean } \\
\text { difference }\end{array}$ \\
\hline & Mean & Mean & t-test & Mean & Mean & t-test \\
\hline FinTech finance & 2.882 & 3.528 & $-0.645 * * *$ & 3.443 & 3.542 & -0.099 \\
\hline Finance_apply & 0.294 & 0.351 & -0.057 & 0.366 & 0.342 & 0.024 \\
\hline $\mathrm{R} \& \mathrm{D}$ intensity & 3.076 & 2.342 & $0.734 * * *$ & 2.247 & 2.421 & $-0.0174 * *$ \\
\hline Finance difficulty & 3.882 & 4.150 & -0.267 & 4.190 & 4.119 & 0.070 \\
\hline Firm year & 15.970 & 7.977 & $7.993 * * *$ & 8.008 & 8.304 & -0.297 \\
\hline Growth & 2.029 & 1.967 & 0.061 & 1.954 & 1.977 & -0.024 \\
\hline Assets & 7799.295 & 5138.066 & 2661.228 & 5364.457 & 5140.820 & 223.637 \\
\hline Risk-preference & 0.088 & 0.057 & 0.031 & 0.072 & 0.052 & $0.020^{*}$ \\
\hline Export & 0.176 & 0.319 & $-0.143 * *$ & 0.282 & 0.332 & $-0.050^{* *}$ \\
\hline Internal_finance & 0.558 & 0.675 & $-0.117^{*}$ & 0.774 & 0.622 & $0.152 * * *$ \\
\hline External debt & 0.588 & 0.717 & $-0.129 * *$ & 0.708 & 0.717 & -0.009 \\
\hline External equity & 0.235 & 0.112 & $0.122 * *$ & 0.108 & 0.121 & -0.013 \\
\hline National bank & 0.559 & 0.715 & $-0.156^{* *}$ & 0.728 & 0.702 & 0.026 \\
\hline Local bank & 0.323 & 0.217 & $0.106^{*}$ & 0.226 & 0.218 & 0.008 \\
\hline Non-bank & 0.058 & 0.051 & 0.007 & 0.049 & 0.053 & -0.004 \\
\hline Bank year & 3.241 & 2.811 & $0.429 * *$ & 2.924 & 2.770 & $0.154 * *$ \\
\hline Collateral & 0.551 & 0.568 & -0.017 & 0.549 & 0.548 & 0.001 \\
\hline Government fund & 1.235 & 1.039 & $0.195 * *$ & 1.031 & 1.053 & -0.022 \\
\hline
\end{tabular}

Notes: Asterisks denote significance at the *.10,**.05 and ***.01 level 
Table 3 Variable correlations

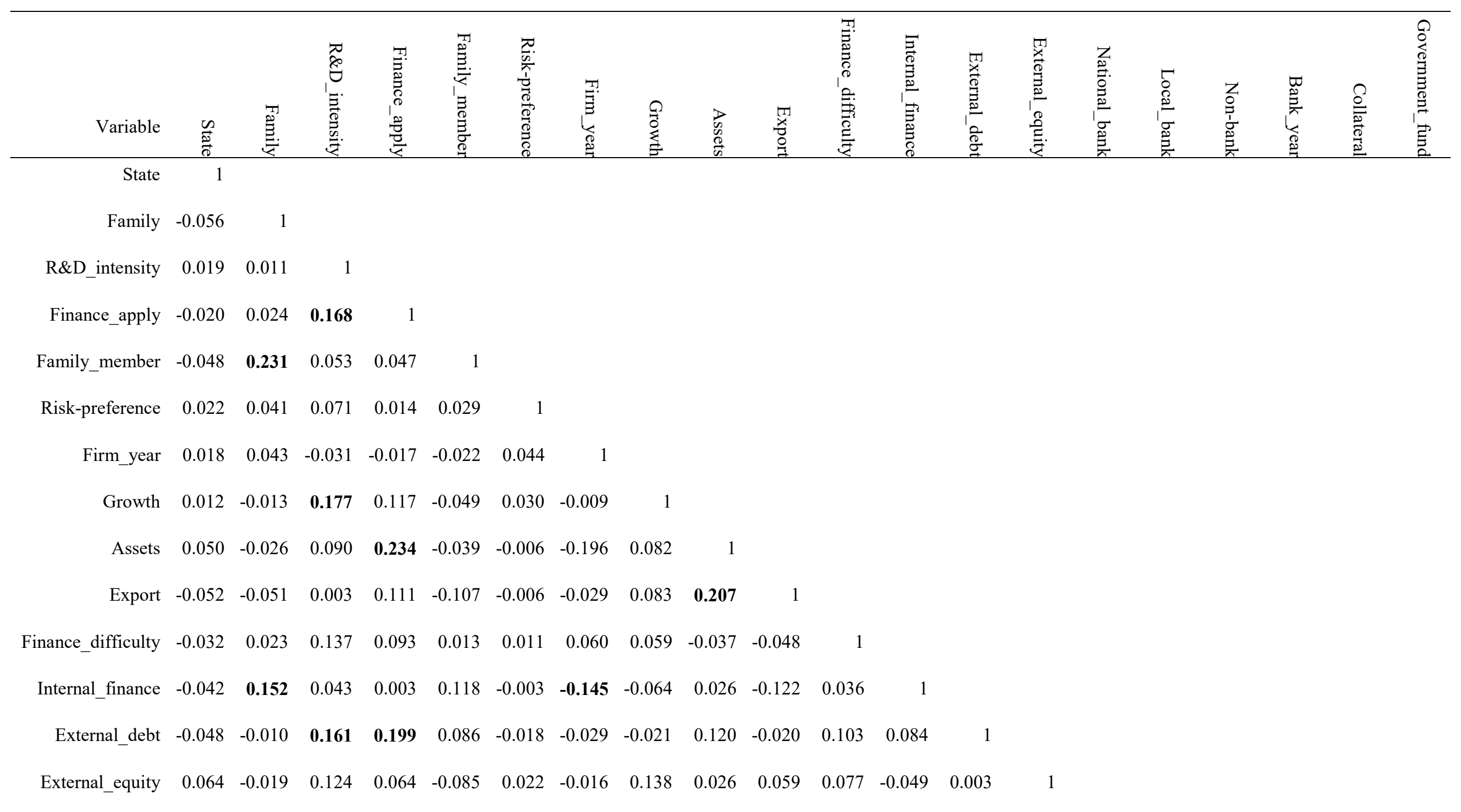




\begin{tabular}{|c|c|c|c|c|c|c|c|c|c|c|c|c|c|c|c|c|c|c|c|c|}
\hline National_bank & -0.058 & 0.027 & 0.081 & 0.086 & 0.101 & 0.024 & -0.013 & -0.050 & 0.186 & -0.063 & 0.078 & 0.015 & 0.045 & -0.047 & 1 & & & & & \\
\hline Local_bank & 0.043 & 0.009 & -0.016 & 0.003 & -0.030 & -0.028 & -0.001 & 0.029 & -0.070 & 0.051 & -0.013 & 0.024 & 0.071 & 0.067 & -0.685 & 1 & & & & \\
\hline Non-bank & 0.006 & -0.009 & 0.044 & -0.011 & -0.022 & 0.056 & -0.012 & -0.005 & -0.150 & -0.019 & -0.043 & 0.032 & 0.029 & -0.013 & -0.289 & -0.087 & 1 & & & \\
\hline Bank_year & -0.041 & 0.016 & -0.011 & -0.104 & -0.025 & 0.034 & -0.007 & -0.078 & -0.177 & -0.092 & 0.007 & 0.040 & -0.023 & -0.064 & -0.041 & 0.001 & 0.136 & 1 & & \\
\hline Collateral & 0.004 & 0.000 & 0.091 & 0.154 & 0.083 & -0.021 & -0.163 & -0.061 & 0.218 & -0.008 & 0.008 & 0.231 & 0.323 & -0.014 & 0.135 & -0.029 & -0.057 & -0.061 & 1 & \\
\hline Government_fund & 0.051 & -0.016 & 0.281 & 0.111 & 0.045 & 0.056 & -0.087 & 0.108 & 0.029 & 0.097 & 0.148 & -0.001 & 0.069 & 0.147 & 0.043 & 0.029 & 0.049 & -0.048 & -0.023 & 1 \\
\hline
\end{tabular}


Table 4 Collinearity diagnostics

\begin{tabular}{|c|c|c|c|c|}
\hline Variable & VIF & $\sqrt{V I F}$ & Tolerance & $\mathrm{R}^{2}$ \\
\hline State & 1.030 & 1.020 & 0.968 & 0.033 \\
\hline Family & 1.090 & 1.040 & 0.919 & 0.081 \\
\hline $\mathrm{R} \& \mathrm{D}$ _intensity & 1.190 & 1.090 & 0.843 & 0.157 \\
\hline Finance_apply & 1.150 & 1.070 & 0.867 & 0.133 \\
\hline Family_member & 1.110 & 1.050 & 0.899 & 0.101 \\
\hline Risk-preference & 1.020 & 1.010 & 0.982 & 0.018 \\
\hline Firm_year & 1.100 & 1.050 & 0.908 & 0.092 \\
\hline Growth & 1.090 & 1.040 & 0.919 & 0.081 \\
\hline Assets & 1.270 & 1.130 & 0.785 & 0.215 \\
\hline Export & 1.120 & 1.060 & 0.896 & 0.104 \\
\hline Finance_difficulty & 1.070 & 1.030 & 0.934 & 0.066 \\
\hline Internal_finance & 1.130 & 1.060 & 0.884 & 0.116 \\
\hline External_debt & 1.210 & 1.100 & 0.828 & 0.172 \\
\hline External_equity & 1.070 & 1.030 & 0.937 & 0.063 \\
\hline National_bank & 2.700 & 1.640 & 0.371 & 0.629 \\
\hline Local_bank & 2.390 & 1.550 & 0.419 & 0.581 \\
\hline Non-bank & 1.390 & 1.180 & 0.718 & 0.282 \\
\hline Bank_year & 1.070 & 1.030 & 0.934 & 0.066 \\
\hline Collateral & 1.270 & 1.130 & 0.790 & 0.211 \\
\hline Govrnment_fund & 1.170 & 1.080 & 0.854 & 0.146 \\
\hline Mean & 1.280 & 1.120 & 0.833 & 0.167 \\
\hline
\end{tabular}


Table 5 State ownership, innovation, and FinTech finance

\begin{tabular}{|c|c|c|c|c|c|c|}
\hline \multirow[t]{2}{*}{ Dep. variable } & \multicolumn{2}{|c|}{ Finance apply } & \multicolumn{4}{|c|}{ FinTech_finance } \\
\hline & (1) & (2) & (3) & (4) & (5) & (6) \\
\hline & Coef. & $\begin{array}{l}\text { Marginal } \\
\text { effect }\end{array}$ & Coef. & Odds ratio & Coef. & Odds ratio \\
\hline State & $\begin{array}{l}-0.137 \\
(0.257)\end{array}$ & -0.044 & $\begin{array}{c}-0.951 * * * \\
(0.335)\end{array}$ & 0.387 & $\begin{array}{c}-0.828 * * \\
(0.384)\end{array}$ & 0.437 \\
\hline Family & $\begin{array}{c}0.057 \\
(0.088)\end{array}$ & 0.018 & & & & \\
\hline R\&D_intensity & $\begin{array}{l}0.059 * * \\
(0.024)\end{array}$ & 0.019 & $\begin{array}{l}0.074 * \\
(0.041)\end{array}$ & 1.076 & $\begin{array}{l}-0.031 \\
(0.163)\end{array}$ & 0.969 \\
\hline Finance_apply & & & $\begin{array}{l}0.234 * * \\
(0.119)\end{array}$ & 1.264 & $\begin{array}{l}0.239 * * \\
(0.119)\end{array}$ & 1.269 \\
\hline Family_member & $\begin{array}{c}0.094 \\
(0.085)\end{array}$ & 0.030 & & & & \\
\hline $\begin{array}{l}\text { State*R\&D_inte } \\
\text { ncitv }\end{array}$ & & & & & $\begin{array}{l}-0.054 \\
(0.745)\end{array}$ & 0.947 \\
\hline Risk-preference & $\begin{array}{c}0.009 \\
(0.174)\end{array}$ & 0.003 & $\begin{array}{c}0.162 \\
(0.232)\end{array}$ & 1.176 & $\begin{array}{c}0.168 \\
(0.233)\end{array}$ & 1.183 \\
\hline Firm_year & $\begin{array}{c}0.010 \\
(0.007)\end{array}$ & 0.003 & $\begin{array}{l}0.022 * * \\
(0.010)\end{array}$ & 1.022 & $\begin{array}{c}0.016 \\
(0.010)\end{array}$ & 1.016 \\
\hline Growth & $\begin{array}{c}0.136^{* * * *} \\
(0.049)\end{array}$ & 0.043 & $\begin{array}{c}0.138 \\
(0.092)\end{array}$ & 1.148 & $\begin{array}{c}0.074 \\
(0.085)\end{array}$ & 1.077 \\
\hline Assets & $\begin{array}{c}0.094 * * * \\
(0.020)\end{array}$ & 0.030 & $\begin{array}{c}0.004 \\
(0.050)\end{array}$ & 1.004 & $\begin{array}{l}-0.051 \\
(0.042)\end{array}$ & 0.951 \\
\hline Export & $0.172 *$ & 0.055 & 0.196 & 1.217 & 0.101 & 1.106 \\
\hline $\begin{array}{l}\text { Finance_difficul } \\
\text { ty }\end{array}$ & $\begin{array}{c}(0.091) \\
0.077 * * * \\
(0.030)\end{array}$ & 0.024 & $\begin{array}{c}(0.136) \\
0.539 * * * \\
(0.058)\end{array}$ & 1.714 & $\begin{array}{c}(0.128) \\
0.496^{* * *} \\
(0.054)\end{array}$ & 1.642 \\
\hline Internal_finance & $\begin{array}{l}-0.064 \\
(0.090)\end{array}$ & -0.020 & $\begin{array}{l}-0.019 \\
(0.118)\end{array}$ & 0.981 & $\begin{array}{c}0.011 \\
(0.117)\end{array}$ & 1.011 \\
\hline External_debt & $\begin{array}{c}0.450 * * * \\
(0.102)\end{array}$ & 0.143 & $\begin{array}{c}0.090 \\
(0.258)\end{array}$ & 1.094 & $\begin{array}{l}-0.186 \\
(0.223)\end{array}$ & 0.830 \\
\hline External_equity & $\begin{array}{c}0.133 \\
(0.125)\end{array}$ & 0.042 & $\begin{array}{c}0.357 * * \\
(0.179)\end{array}$ & 1.429 & $\begin{array}{l}0.296^{*} \\
(0.177)\end{array}$ & 1.344 \\
\hline National_bank & $\begin{array}{l}0.306^{* *} \\
(0.153)\end{array}$ & 0.098 & $\begin{array}{l}-0.076 \\
(0.237)\end{array}$ & 0.927 & $\begin{array}{l}-0.247 \\
(0.222)\end{array}$ & 0.781 \\
\hline Local_bank & $\begin{array}{c}0.240 \\
(0.156)\end{array}$ & 0.076 & $\begin{array}{l}-0.076 \\
(0.221)\end{array}$ & 0.927 & $\begin{array}{l}-0.208 \\
(0.211)\end{array}$ & 0.812 \\
\hline Non-bank & $\begin{array}{l}0.454 * * \\
(0.219)\end{array}$ & 0.145 & $\begin{array}{c}-0.710 * * \\
(0.346)\end{array}$ & 0.492 & $\begin{array}{c}-0.943 * * * \\
(0.325)\end{array}$ & 0.389 \\
\hline Bank_year & $\begin{array}{l}-0.173 \\
(0.126)\end{array}$ & -0.055 & $\begin{array}{l}0.401 * * \\
(0.176)\end{array}$ & 1.493 & $\begin{array}{c}0.513 * * * \\
(0.168)\end{array}$ & 1.670 \\
\hline
\end{tabular}




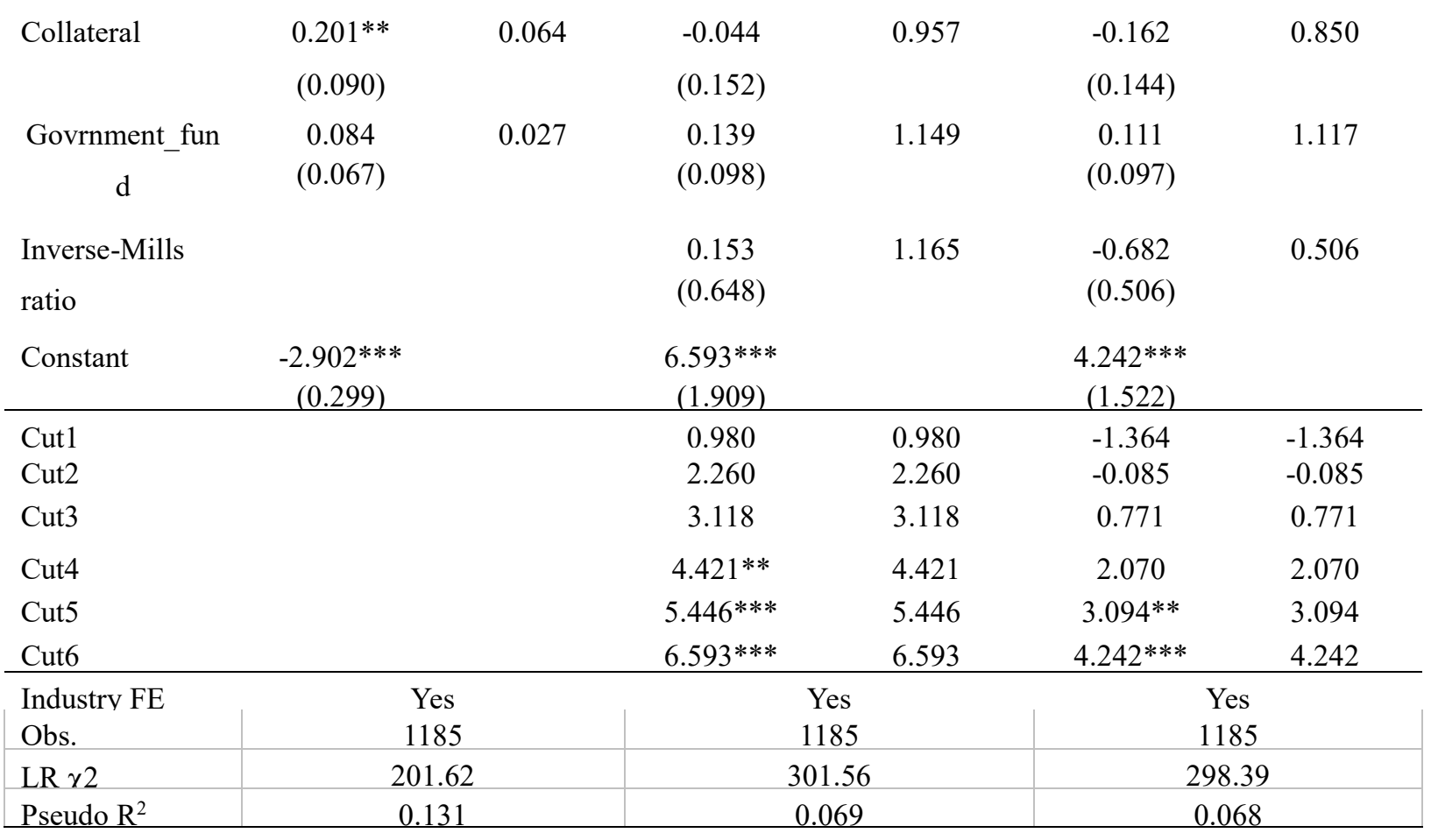

Notes: Standard errors in parentheses. Asterisks denote significance at the *.10,**.05 and ***.01 level. 
Table 6 Family ownership, innovation, and FinTech finance

\begin{tabular}{|c|c|c|c|c|c|c|}
\hline Dep. variable & $\begin{array}{c}\text { FinTech_fina } \\
(1) \\
\text { Coef. } \\
\end{array}$ & $\begin{array}{l}\text { e } \\
\text { (2) } \\
\text { Odds ratio }\end{array}$ & $\begin{array}{c}(3) \\
\text { Coef. }\end{array}$ & $\begin{array}{c}\text { (4) } \\
\text { Odds ratio }\end{array}$ & $\begin{array}{l}(5) \\
\text { Coef. }\end{array}$ & $\begin{array}{c}\text { (6) } \\
\text { Odds ratio }\end{array}$ \\
\hline Family & $\begin{array}{c}-0.239^{* *} \\
(0.118)\end{array}$ & 0.787 & $\begin{array}{c}-0.308^{* *} \\
(0.120)\end{array}$ & 0.735 & $\begin{array}{c}-0.314 * * * \\
(0.120)\end{array}$ & 0.730 \\
\hline State & & & & & $\begin{array}{c}-0.861 * * * \\
(0.332)\end{array}$ & 0.423 \\
\hline R\&D_intensity & $\begin{array}{c}0.004 \\
(0.043)\end{array}$ & 1.004 & $\begin{array}{l}-0.700^{*} \\
(0.380)\end{array}$ & 0.497 & $\begin{array}{l}-0.689^{*} \\
(0.379)\end{array}$ & 0.502 \\
\hline Finance_apply & $\begin{array}{l}0.227^{*} \\
(0.119)\end{array}$ & 1.255 & $\begin{array}{l}0.215^{*} \\
(0.119)\end{array}$ & 1.240 & $\begin{array}{l}0.217^{*} \\
(0.119)\end{array}$ & 1.242 \\
\hline Family_member & $\begin{array}{c}-0.361 * * * \\
(0.120)\end{array}$ & 0.697 & $\begin{array}{c}-0.371 * * * \\
(0.116)\end{array}$ & 0.690 & $\begin{array}{c}-0.369 * * * \\
(0.116)\end{array}$ & 0.691 \\
\hline $\begin{array}{l}\text { Family*R\&D_i } \\
\text { ntensitv }\end{array}$ & & & $\begin{array}{c}1.592 * * * \\
(0.578)\end{array}$ & 4.913 & $\begin{array}{c}1.593 * * * \\
(0.577)\end{array}$ & 4.918 \\
\hline Risk-preference & $\begin{array}{c}0.158 \\
(0.235)\end{array}$ & 1.171 & $\begin{array}{c}0.190 \\
(0.235)\end{array}$ & 1.209 & $\begin{array}{c}0.209 \\
(0.234)\end{array}$ & 1.233 \\
\hline Firm_year & $\begin{array}{c}0.009 \\
(0.010)\end{array}$ & 1.010 & $\begin{array}{c}0.010 \\
(0.010)\end{array}$ & 1.010 & $\begin{array}{c}0.013 \\
(0.010)\end{array}$ & 1.013 \\
\hline Growth & $\begin{array}{l}-0.021 \\
(0.096)\end{array}$ & 0.979 & $\begin{array}{l}-0.030 \\
(0.087)\end{array}$ & 0.970 & $\begin{array}{l}-0.006 \\
(0.088)\end{array}$ & 0.994 \\
\hline Assets & $\begin{array}{c}-0.111^{* *} \\
(0.053)\end{array}$ & 0.895 & $\begin{array}{c}-0.112 * * * \\
(0.042)\end{array}$ & 0.894 & $\begin{array}{c}-0.093 * * \\
(0.043)\end{array}$ & 0.911 \\
\hline Export & $\begin{array}{c}0.000 \\
(0.143)\end{array}$ & 1.000 & $\begin{array}{l}-0.015 \\
(0.130)\end{array}$ & 0.985 & $\begin{array}{l}-0.012 \\
(0.130)\end{array}$ & 0.988 \\
\hline $\begin{array}{l}\text { Finance_difficul } \\
\text { ty }\end{array}$ & $\begin{array}{c}0.449 * * * \\
(0.060)\end{array}$ & 1.567 & $\begin{array}{c}0.452 * * * \\
(0.054)\end{array}$ & 1.572 & $\begin{array}{c}0.466^{* * *} \\
(0.055)\end{array}$ & 1.594 \\
\hline Internal_finance & $\begin{array}{c}0.113 \\
(0.121)\end{array}$ & 1.120 & $\begin{array}{c}0.102 \\
(0.119)\end{array}$ & 1.107 & $\begin{array}{c}0.084 \\
(0.120)\end{array}$ & 1.087 \\
\hline External_debt & $\begin{array}{l}-0.449^{*} \\
(0.275)\end{array}$ & 0.639 & $\begin{array}{c}-0.467 * * \\
(0.224)\end{array}$ & 0.627 & $\begin{array}{l}-0.407 * \\
(0.225)\end{array}$ & 0.666 \\
\hline External_equity & $\begin{array}{c}0.134 \\
(0.181)\end{array}$ & 1.144 & $\begin{array}{c}0.100 \\
(0.178)\end{array}$ & 1.105 & $\begin{array}{c}0.144 \\
(0.179)\end{array}$ & 1.155 \\
\hline National_bank & $\begin{array}{l}-0.375 \\
(0.243)\end{array}$ & 0.687 & $\begin{array}{l}-0.381^{*} \\
(0.223)\end{array}$ & 0.683 & $\begin{array}{l}-0.343 \\
(0.223)\end{array}$ & 0.710 \\
\hline Local_bank & $\begin{array}{l}-0.327 \\
(0.225)\end{array}$ & 0.721 & $\begin{array}{l}-0.323 \\
(0.212)\end{array}$ & 0.724 & $\begin{array}{l}-0.278 \\
(0.212)\end{array}$ & 0.757 \\
\hline Non-bank & $\begin{array}{c}-1.198 * * * \\
(0.357)\end{array}$ & 0.302 & $\begin{array}{c}-1.161 * * * \\
(0.328)\end{array}$ & 0.313 & $\begin{array}{c}-1.096^{* * *} \\
(0.329)\end{array}$ & 0.334 \\
\hline Bank_year & $\begin{array}{c}0.606^{* * *} \\
(0.179)\end{array}$ & 1.834 & $\begin{array}{c}0.621 * * * \\
(0.168)\end{array}$ & 1.860 & $\begin{array}{c}0.583 * * * \\
(0.169)\end{array}$ & 1.792 \\
\hline
\end{tabular}




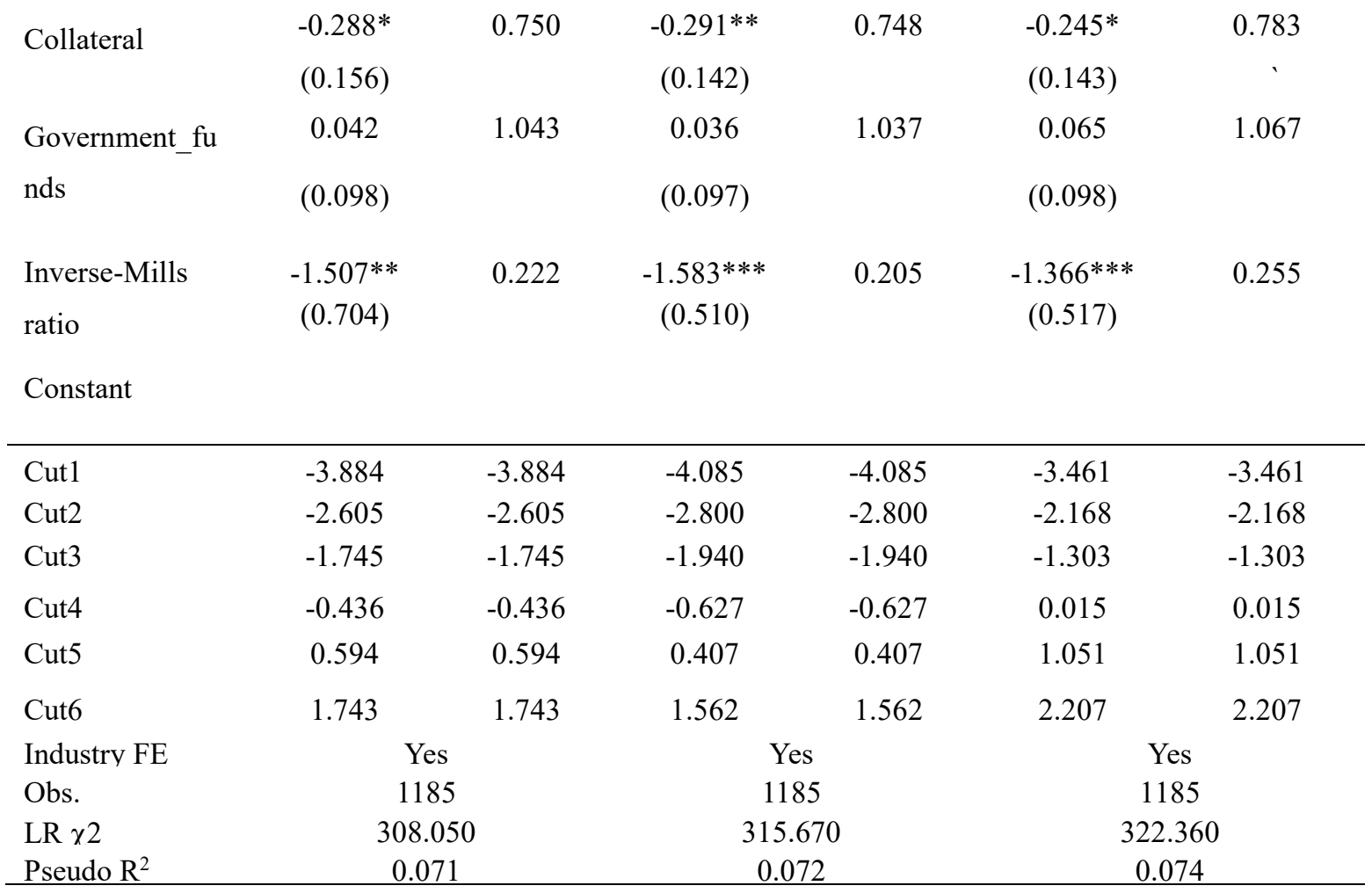

Notes: Standard errors in parentheses. Asterisks denote significance at the * $.10,{ }^{* *} .05$ and ${ }^{* * *} .01$ level. 